\title{
A Comparison of the Development of Wetland Restoration Techniques in China and Other Nations
}

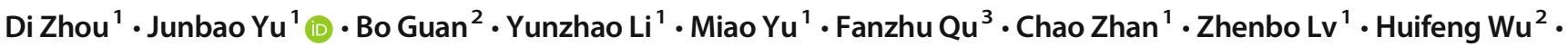 \\ Qing Wang ${ }^{1} \cdot$ Jisong Yang ${ }^{1,4}$
}

Received: 7 November 2019 / Accepted: 24 April 2020

(C) Society of Wetland Scientists 2020

\begin{abstract}
Based on retrieved results of literature and patents related to international wetland ecological restoration, the current status and development of ecological restoration techniques for degraded wetlands in both China and international states were analyzed synthetically. The results showed that the United States was the pioneering country in studies on the wetland ecological restoration, while China began to pay widespread attention from 2000. Compared to the international developed countries, the start time of concern for wetland ecological restoration in China was about 10 years later. The phytoremediation and engineering restoration were the most popular among all the wetland ecological restoration techniques. Besides the United States, the number of publications increased most quickly in China since 2004. The Louisiana State University published most of the researching findings among the international institutions related to wetland ecological restoration. The Chinese Academy of Sciences was the most important institution for wetland restoration study in China. The analysis of the wetland ecological restoration practice in China and international states indicated that the study and application of combined bioremediation techniques would receive more attention for wetland ecological restoration in the future.
\end{abstract}

Keywords Degraded wetland $\cdot$ Ecological restoration technique $\cdot$ Development trend $\cdot$ Phytoremediation $\cdot$ Current status $\cdot$ China

Junbao Yu

junbao.yu@gmail.com; jbyu@1du.edu.cn

$\triangle$ Jisong Yang

yjswill@126.com

1 Key Laboratory of Ecological Restoration and Conservation of Coastal Wetlands in Universities of Shandong, The Institute for Advanced Study of Coastal Ecology, Ludong University, Yantai 264003, People's Republic of China

2 Key Laboratory of Coastal Environmental Processes and Ecological Remediation, Chinese Academy of Sciences, Yantai Institute of Coastal Zone Research, Yantai 264003, People's Republic of China

3 Shandong Provincial Key Laboratory of Eco-Environmental Science for Yellow River Delta, Binzhou University, Binzhou 256601, People's Republic of China

4 Key Laboratory of Ecological Restoration and Conservation of Coastal Wetlands in Universities of Shandong, The Institute for Advanced Study of Coastal Ecology, Ludong University, Yantai 264025, People's Republic of China

\section{Introduction}

Wetlands, caused by the interaction of land and water, are one of the most important and irreplaceable ecosystems with diverse ecological functions, i.e. biodiversity protection, water storage, groundwater replenishment, retention of nutrients, sediment and other substances, storehouses (sinks) of carbon, etc. (Mitsch and Gosselink 2000; Ullah and Faulkner 2006). Wetlands distribute in each continent except Antarctic and the area of global wetlands is $7 \times 10^{6}-9 \times 10^{6} \mathrm{~km}^{2}$, occupying $4 \%$ - 6\% of the earth's surface (Matthews and Fung 1987; Aselmann and Crutzen 1989; Mitsch and Gosselink 1993). Therefore, wetlands together with cropland, forest land and grassland are called four major terrestrial ecosystems (Ma et al. 2017; Chen et al. 2013). Robert Costanza et al. (1997) estimated the value of our natural ecosystems was about US\$ 33 trillion, and the global value of wetland was about US\$ 14.9 trillion, $45 \%$ of the total. Unfortunately, wetland is one of the most threatened territory ecosystems in the world because of the land use change and the disturbance of human activities. Since the beginning of the twentieth century, a large area of wetland has been developed and numerous important 
wetlands in the world have disappeared sharply with the rapid growth of economy (Coleman et al. 2008; McCauley et al. 2013; Ahmed 2014; Lin and Yu 2018; Rebelo et al. 2018; Lamsal et al. 2019; Shen et al. 2019). About 90\% wetlands have been destroyed or under serious degradation in many countries, resulting in severe losses in biodiversity and wetland's functions (Holland et al. 1995; Kingsford and Thomas 2002; Wang et al. 2012; McCauley et al. 2013). According to estimation of World Conservation Monitoring Centre (1990), about $50 \%$ wetlands in the world have disappeared from the earth's surface. American wetland has lost 87 million $\mathrm{hm}^{2}$, accounting for about $54 \%$ of the total wetland area in USA, which were mainly used for agricultural production (Kesel 1989; Foy 1990; Allen and Feddema 1996; Coleman et al. 2008; Tweel and Turner 2012; Ryan et al. 2014). The average wetland loss in Europe was about $60 \%$ of the total area (Holland et al. 1995; Coleman et al. 2008; Paganelli and Sconfietti 2013). More than half of wetland in Asia has been lost and over 50\% mangroves in India-Malaysia region have been deforested for aquaculture (Foote et al. 1996; Scott and Metts 2012). The coastal tidal wetlands in China have lost more than $50 \%$ of its total area since 1950s (Zhang et al. 2010; Yu et al. 2011; Wang et al. 2012; Li et al. 2014a; Sun et al. 2016). The loss rate of wetlands around the world is still astonishing at present (Rains et al. 2013; Li et al. 2014a; Ryan et al. 2014; Van Rees and Reed 2014). In order to protect and remediate degraded natural wetland ecosystems, the developed countries have started to carry out the research and practice projects about degraded wetlands' restoration and reconstruction since 1970s (Moss 1983; Zentner 1985; Lewis et al. 1994). Then, more and more funds have been established to support the protection and recovery of endangered wetlands with the global awareness of biodiversity conservation since 1990 (Bartels and Anderson 1993; Tuttle and Gray 1993; Goodwin 1994; Bijlmakers and Deswart 1995; Weller 1995; Zhao et al. 2016). Meanwhile, large numbers of researches related to degraded wetland vegetation restoration and reconstruction are carried out. The degraded wetland restoration techniques dominated by physical restoration, chemical restoration and bioremediation are developed and matured gradually (Goodwin 1994; Wetzel et al. 2001; Holden et al. 2004; Watts and Didham 2006; Guan et al. 2013; Hurry et al. 2013; Huang et al. 2016; Ivajnsic et al. 2016; Cui et al. 2018). In this study, the literature and patents were related to international wetland ecological restoration from Science Citation Index Expanded database in ISI Web of Science, CNKI Chinese Scientific Journal database, ISI Derwent Innovations Index database, Soopat patent database and CAS patent-online analysis system (http://patent.casip.ac.cn/pat2/view/m05/A0500. xhtml). The key words for literature and patents retrieval were (marsh, bog, wetland, swamp, Fen, peat land, river, lake, pond) \& (ecological restoration, ecological remediation). The retrieval results were further manually filtered. The publication time, author address, restoration technology and other necessary information were manually checked based on the content of each literature and patent. Based on the final retrieved results, the research status and the development of restoration technology for degraded wetlands in China and the international states were reviewed comprehensively. It is worth comparing the advantages and disadvantages of related techniques and estimating the disparity of the degraded wetland restoration techniques at different development stages between China and international states, in order to further develop and improve the core ecological restoration techniques for degraded wetlands.

\section{Development Stage of Degraded Wetland Ecological Restoration}

The initial research on degraded wetland began in 1970s, with the main purpose of protection and restoration of nature degraded wetland ecosystem (Moss 1983; Zechner et al. 2003). By 1980s, the restoration ecology has been developing rapidly (Zechner et al. 2003; Peters et al. 2015; Zhao et al. 2016). The International Association for Ecology was founded in 1985 and the professional journal of "Restoration Ecology" was established in 1993. Thereafter, a large number of monographs, journals and papers related to restoration ecology symbolize that the ecological restoration studies becomes more and more active and concerned (Keddy 1999; Pfadenhauer and Grootjans 1999; Zedler 2000; Marchetti et al. 2010; Cui et al. 2018). The theme of the Fifth International Wetlands Conference was "Future of Wetland" and the main issues included how to enhance the benefit of wetland, preventing the wetland loss, function decline, biodiversity decrease, as well as the strategies and measures for wetland protection and reconstruction. Thereafter, the wetland restoration and reconstruction has become a common concern and a research hotpot for scientists. The current research of wetland restoration and reconstruction concentrated on the wetland types of swamps, lakes, rivers and coastal wetlands (Mitsch 2005; Nakamura et al. 2006; Tweel and Turner 2012; Li et al. 2014b; Ma et al. 2015; Moreno-Mateos et al. 2015; Cui et al. 2018).

The restoration and reconstruction of damaged wetlands studies were carried out early in the United States (Zentner 1985). The 313 wetland restoration research projects related to cleaning lake project which was proposed by U.S. Environmental Protection Agency were funded by government of USA during 1975 to 1985 (Wang 2008). These projects included the wastewater discharge control, feasibility study and response assessment of restoration plans, lake classification and nutrition status of lake, etc. (Wang 2008). The American Water Science and Technology Division evaluated 
the wetland restoration project which was carried out by the National Research Council in 1988. The overall evaluation including science, technology, policies and regulations of wetland restoration was carried out by the Water Ecosystem Remediate Committee of USA in 1989. With the total investment of $\$ 685$ million, a wetland project which aimed at the rebuilding of Florida everglades was conducted in United States in 1995 (Weller 1995). The Federal government was allocated special funds of $\$ 200$ million for the ecological restoration in the upper Mississippi river and the wetland ecological restoration was a critical component (Callahan and Heard 1994; Hey and Philippi 1995; Rothe 1995; Theiling et al. 2015). Some European countries such as Sweden, Spain, Switzerland and Denmark have also made great advances on wetland restoration research (Tuttle and Gray 1993; Bijlmakers and Deswart 1995; Stuurman and de Louw 2000; MartinezSantos et al. 2008). The restoration projects in Austria, Belgium, France, Germany, Hungary, Holland, Switzerland, and UK mainly concentrated in flood plain (Tuttle and Gray 1993; Schneider 2014; Elliott et al. 2016). By planting aquatic plants, the lakes built for the deposition of rare metal ores nearby Capel, Australia, have been restored to a healthy wetland ecosystem. The degraded riparian ecosystem of the Rihand River (India) under extensive deforestation, dam construction, industrialization process and open-cast mining has been improved and restored by taking protective measures such as grazing exclusion, sewage division and treatment and native vegetation restoration. In Vietnam, the massive drainage in Mekong Delta resulted in the serious ecological degradation of 750,000 $\mathrm{hm}^{2}$ tidal freshwater wetlands. In order to improve the natural hydrological processes of $7000 \mathrm{hm}^{2}$ wetlands, dams were built since 1988. The ecological engineering technique of oxidation pond based on the symbiosis of bacterial and algae was firstly used by the Institute of Hydrobiology, Chinese Academy of Sciences in 1970s. The technique greatly improved the seriously polluted environment of Yaer Lake area, Hubei province and promoted the study of wetland restoration in China. After then, the wetland restoration research successively developed in Taihu of Jiangsu, Chaohu in Anhui, East Lake in Wuhan and coastal wetland. Since 1998 when the catastrophic flood occurred in Yangtze River Basin, the "Returning farmland to lake" has been regarded as an important content of sustainable development and ecological reconstruction in China (Liu et al. 2004; Ma et al. 2015). In recent years, the coastal wetland restoration research mainly based on the fresh water resources regulation and the nutrient biogeochemstry in the Yellow River Delta, has become one of the core technologies for ecological restoration in degraded coastal wetland (Cui et al. 2009; Wang et al. 2012; Guan et al. 2013).

Currently, the international wetland restoration method mainly focuses on restoration of hydrological conditions in damaged wetland, halophytes and salt-tolerant plant breeding, as well as the species and habitat recovery (Callaway et al.
2003; Acreman et al. 2007; Kim et al. 2011; Rumm et al. 2016). The vegetation could restore gradually when the natural environment was remediated under the seed bank existence (VivianSmith and Handel 1996; Li et al. 2008; Stroh et al. 2012; Beas et al. 2013; Shang et al. 2016). By the study in California and Wisconsin, Zedler (Zedler 2000) found that the different restoration methods should be taken for different regions with different damaged reasons, and the restoration results with multiple species were much effective than that with the single species. The techniques of the condition improvement were mainly applied to develop the dominant plant populations for coastal wetland restoration in North and Western Europe area (Acreman et al. 2007). Although many countries have put forward a large number of schemes for coastal wetland and estuarine wetland restoration, a unified wetland restoration criteria is not proposed up to now. Therefore, we should select the reasonable methods based on the actual conditions and regional characteristics when these schemes were used for wetland restoration.

\section{Key Techniques for Degraded Wetland Ecological Restoration}

Except the combined restoration technology (a new restoration technology formed by combination of two or more restoration technologies such as plant-microbial restoration, constructed wetland, etc.), wetland restoration technology can be basically divided into physical technology, chemical technology and biotechnology (Table 1). Physical technology achieves wetland restoration goals by improving water and soil conditions. Water-soil engineering of physical restoration technology can create a favorable water-soil environment for wetland health and promote self-repair processes in wetlands (Goodwin 1994). The water replenishment technology can eliminate the influence of water shortage and salinity by increasing the water supply (Gyuracz et al. 2011; Ahmed 2014). The sediment dredging can reduce the pollutant accumulation in sediment and the release into water (Sullivan and Aller 1996; Vellidis et al. 2003; Parkinson et al. 2006). However, the problems of high cost for construction and maintenance, large manpower and material resources consuming exist in the physical restoration technology (Goodwin 1994). The chemical restoration technology can improve wetland soil chemical properties by adding chemicals, fertilizing and soil conditioners to make wetland soil beneficial for the plant growth (Portnoy 1999). For example, the chemicals containing ions of aluminum, iron and calcium can rapidly remove the eutrophication pollutants in the sewage by chemical reaction of these ions with nitrogen, phosphorus and other substances in water. The disadvantages of chemical restoration technology include incomplete governance, high cost and secondary pollution (Portnoy 1999; Moreno-Mateos et al. 2015). Microbial use 
Table 1 The basic classification of wetland ecological restoration technology

\begin{tabular}{|c|c|c|c|}
\hline $\begin{array}{l}\text { Restoration } \\
\text { technology }\end{array}$ & Classification & Description & Function \\
\hline \multirow[t]{3}{*}{$\begin{array}{l}\text { Physical } \\
\text { restoration } \\
\text { technology }\end{array}$} & Water-soil Engineering & $\begin{array}{l}\text { Construction of water storage dams, drainage ditches } \\
\text { and change land use to control wetland hydrology } \\
\text { and land utilization }\end{array}$ & $\begin{array}{l}\text { To create a favorable environment for the healthy } \\
\text { development of wetlands }\end{array}$ \\
\hline & Water replenishment & $\begin{array}{l}\text { Water replenishment in water-shortage or saline al- } \\
\text { kali wetland through water conservancy facilities }\end{array}$ & $\begin{array}{l}\text { To increase water supply, eliminating the impact of } \\
\text { water scarcity and salinity }\end{array}$ \\
\hline & Sediment dredging & $\begin{array}{l}\text { Dredge sediment pollution in wetlands by artificial } \\
\text { machinery }\end{array}$ & $\begin{array}{l}\text { To reduce accumulation of pollutants in sediment } \\
\text { and prevent releasing to water body }\end{array}$ \\
\hline \multirow{2}{*}{$\begin{array}{l}\text { Chemical } \\
\text { restoration } \\
\text { technology }\end{array}$} & Chemicals adding & Adding algaecide and precipitating agent, ect. & To control eutrophication \\
\hline & $\begin{array}{l}\text { Fertilization and } \\
\text { ameliorant } \\
\text { application }\end{array}$ & Rational fertilization and adding chemical modifier & $\begin{array}{l}\text { To improve physical and chemical properties of soil } \\
\text { in wetlands }\end{array}$ \\
\hline \multirow[t]{2}{*}{$\begin{array}{l}\text { Bioremediation } \\
\text { technology }\end{array}$} & $\begin{array}{l}\text { Microbial } \\
\text { restoration/Soil fau- } \\
\text { na restoration }\end{array}$ & $\begin{array}{l}\text { Process of transforming toxic pollutants into } \\
\text { non-toxic substance by using microorganisms/soil } \\
\text { fauna naturally occurring or cultured under partic- } \\
\text { ular environment }\end{array}$ & $\begin{array}{l}\text { To increase the degradation process of contaminants } \\
\text { such as petroleum, pesticide and toxic organic } \\
\text { pollutants, fixed heavy metals in wetlands and } \\
\text { remove nitrogen, phosphorus and other nutrients } \\
\text { from wetland. }\end{array}$ \\
\hline & Phytoremediation & $\begin{array}{l}\text { Utilization Plant functions of phytoextraction, } \\
\text { phytovolatilization, roots filter and plant } \\
\text { passivation }\end{array}$ & $\begin{array}{l}\text { To absorb nutrients and heavy metals in the water } \\
\text { and improve saline and alkaline land Aquatic } \\
\text { using high plants }\end{array}$ \\
\hline
\end{tabular}

for polluted wetland restoration or wetland plant breeding is the main pathway of bioremediation (Land et al. 2011). Microbial restoration technology is mainly used for degradation of oil, pesticide, toxic and organic pollutants in wetland, as well as fixes the heavy metals and removing nutrients of nitrogen, phosphorus, etc. (DeMeester and Richter 2010; Land et al. 2011). The principle of fauna restoration which is necessary supplement for traditional bioremediation is that the miniature animal activities can promote the transference, transformation and degradation of pollutants in water (Hagerthey et al. 2014). The phytoremediation mainly utilizes the macrophyte to absorb nutrients, heavy metals and other pollutants in wetland. Up to now, the phytoremediation techniques have not been formed the bioremediation's own standards and system, and it implemented mainly on the basis of the different wetland types and pollution levels (Kentula 2000; Huang et al. 2016; Ivajnsic et al. 2016). Generally, the physical and the chemical methods are mainly used for urban wetlands restoration, while the bioremediation is widely used for natural wetland restoration. The current practical results indicate that the combination of several techniques often gets a satisfied restoration effect. The leaching/extraction, which belong to physical-chemical restoration techniques, can be used to remove intractable organic pollutants in wetland soil. The plant-microbial combined restoration, which increases the wetland restoration effect by coordination of plant and microorganisms, can greatly improve water quality and maintain aquatic ecosystem balance by changing the plant community structure (Zhu et al. 2012).

\section{Comparison of Degraded Wetland Restoration Techniques in China and International Nations}

Since the 1990s, international funds have been increasingly used to establish protection and recovery of endangered
Fig. 1 Comparative analysis of publication related wetland restoration

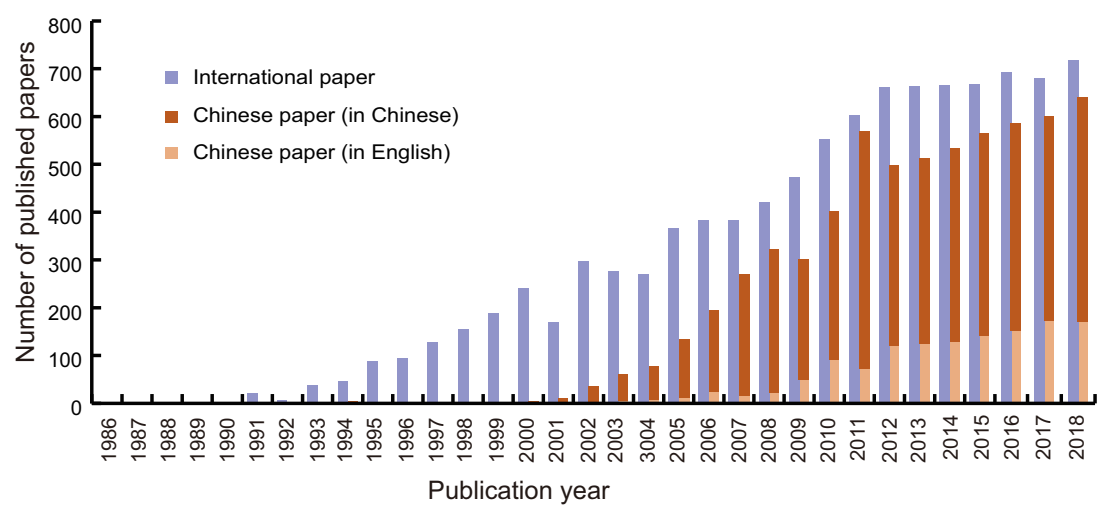


Fig. 2 Comparative analysis of patent on wetland restoration technology (Due to the access limitation, the number of international patents is limited)

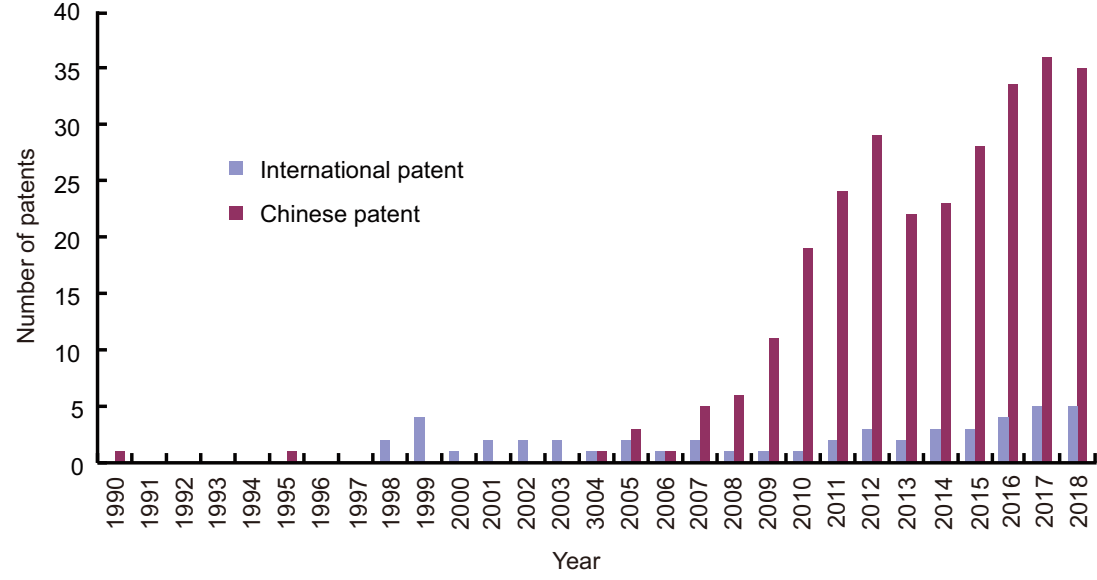

wetlands and enhance global awareness of biodiversity conservation (Bartels and Anderson 1993; Meli et al. 2014). The number of research studies related to vegetation restoration in degraded wetlands was reported in a series of books, monographs, and papers related to wetland restoration, which were published in succession. The retrieved results from the Science Citation Index Expand database of ISI Web of Science and the CNKI Chinese literature retrieval database showed that the numbers of publications related to wetland ecological restoration present an increasing trend year by year both in China and international states (Fig.1).

International papers on wetland restoration began to be published in large numbers from 1990 and increased rapidly. Wetland restoration wasn't paid widespread attention in China until 2000, which was about 10 years after most international developed nations. Although the wetland restoration study in China fell behind of international countries, the numbers of published papers in China were gradually close to the international publications, indicating that the development speed of wetland restoration research in China are much fast.
The check results of international patents from the ISI Derwent Innovations Index, Soopat patent database and CAS patent analysis system (http://patent.casip.ac.cn/pat2/ view/m05/A0500.xhtml) showed that the international patent related to wetland restoration appeared at 1998 and kept a stable number each year. The first patent related to wetland restoration in China was authorized in 1990, and then the annual number of patents increased rapidly after 2006 (Fig. 2), which was much more than that of international patent number because of the access limitation of international patent. From the view of patent types, the physical restoration technique and combined restoration technique were advanced, while the chemical restoration technique and bioremediation technique lagged the international states. The wetland restoration method has been developed gradually from the single and simple technique to combined and complex treatment method, reflecting that the degraded wetland restoration received more and more attention.

The phytoremediation and engineering restoration are regarded as the key point both in China and international nations (Fig. 3). The proportions of international publications
Fig. 3 The proportion of mainstream technologies of international papers $(\mathrm{A})$ and Chinese papers (B) related wetland restoration

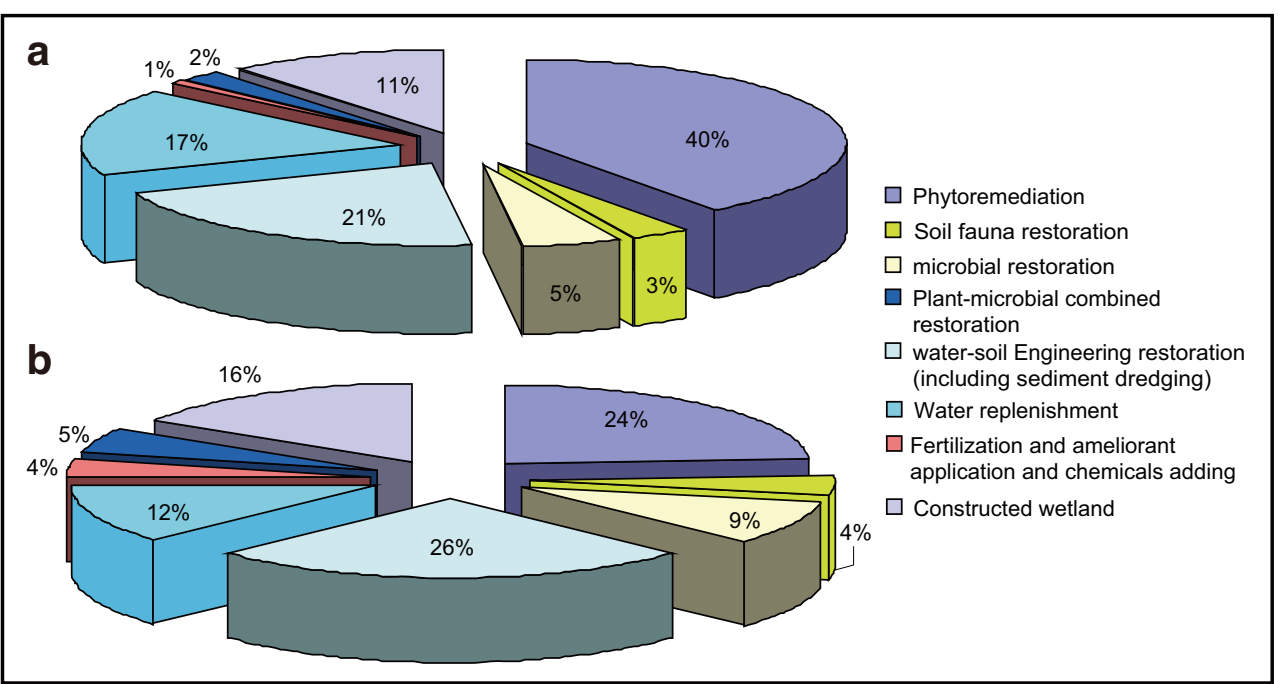


Fig. 4 Numbers of international paper (A) and Chinese paper (B) related the mainstream restoration technologies during 1989-2018

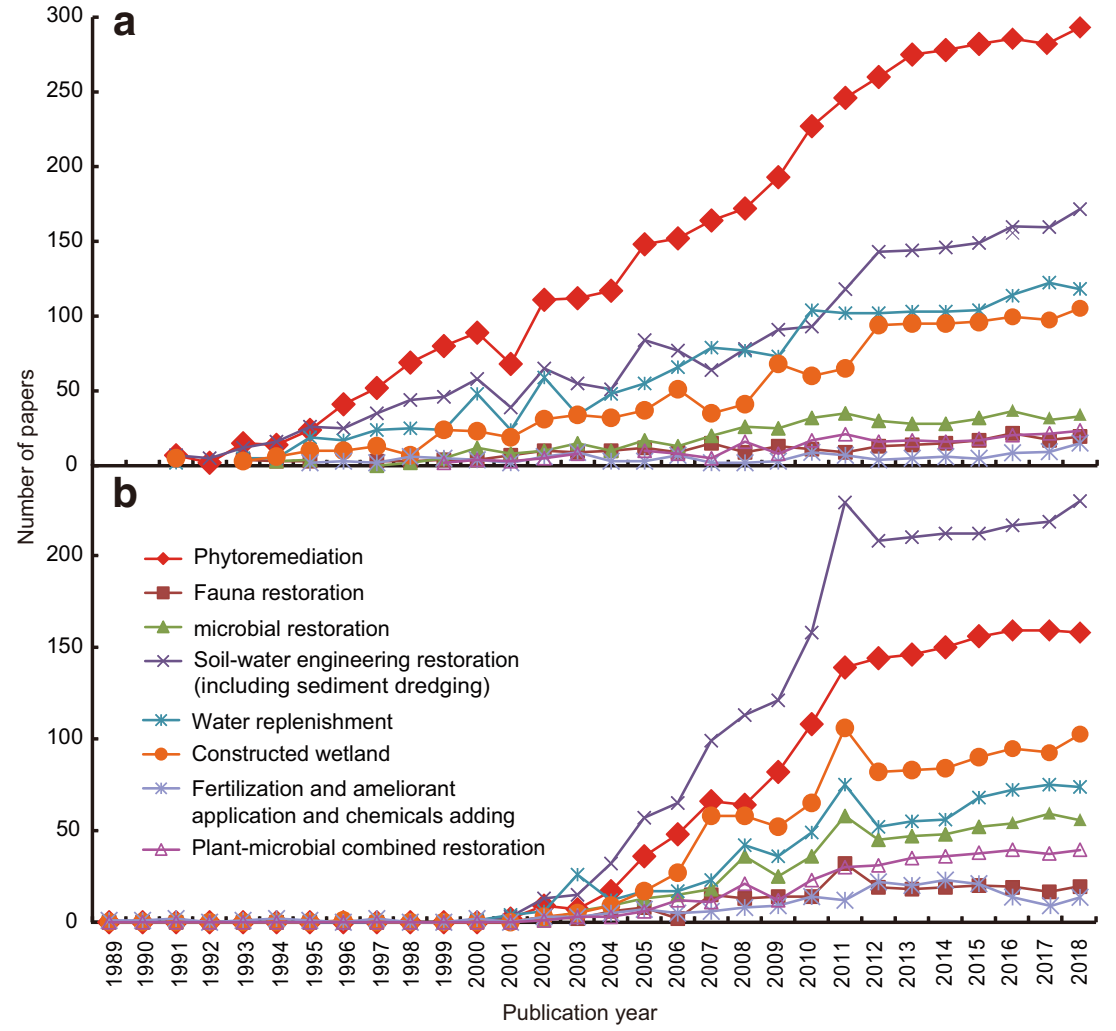

related to phytoremediation and water-soil engineering restoration of total international papers of wetland restoration were $40 \%$ and $21 \%$, respectively (Fig. 3A), and those proportions in China were $26 \%$ and $24 \%$, respectively (Fig. 3B).

Both the international and Chinese scientific papers related to all concern types of wetland restoration techniques showed increasing trends with time increased (Fig. 4A, B). The annual international publications, especially those about phytoremediation, water-soil engineering restoration and water replenishment studies increased quickly since 1990, among which the published paper numbers of phytoremediation occupied a dominant position with the most rapid growth rate, followed by water-soil engineering restoration and water replenishment (Fig. 4A). There were very few published papers related to wetland restorations in China before 2000. Since then, the wetland restoration studies were widespread gradually. The annual increase number of scientific papers about water-soil engineering restoration was highest and those about phytoremediation and artificial wetlands ranked second and third, respectively (Fig. 4B).

The comparative analysis results of publication number on wetland restoration in mainstream countries during 20002018 showed that the maximum of 4044 papers were published by United States, while China ranked second with 1335 English papers, which were much lower than that of the United States (Fig. 5). The development of mainstream restoration techniques of phytoremediation and water-soil engineering restoration in the United States showed a fluctuation growth trend during 2000-2018 and those development trends in China, UK, Canada and other mainstream countries appeared a fast-growing trend since 2004, among which China achieved a great increase rate (Fig. 6A, B).

Regardless of phytoremediation and water-soil engineering restoration, the highest publishing percentage of related papers was published by the Louisiana State University during 2000-2008, the United States Geological Survey ranked second (Fig. 7A, B). The publications related to the phytoremediation and water-soil engineering restoration

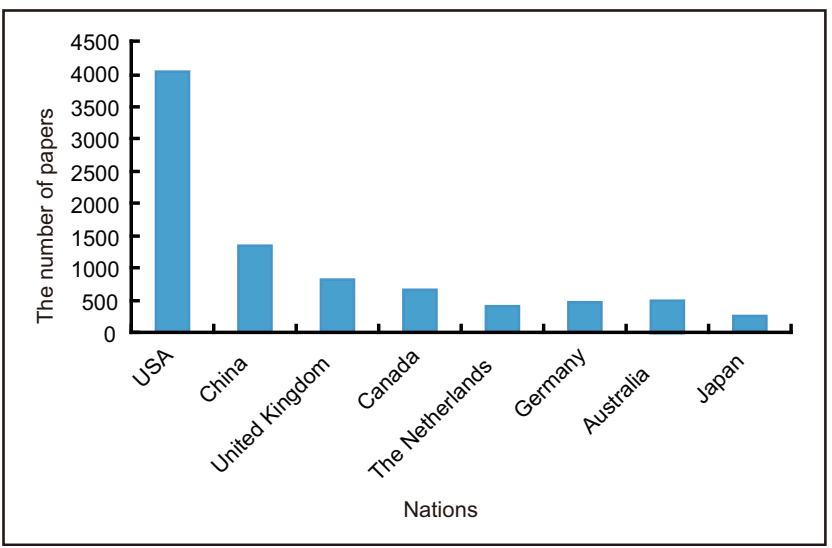

Fig. 5 The total number of English papers related wetland restoration in the mainstream nations during 2000-2018 
Fig. 6 The numbers of international papers on phytoremediation (A) and engineering restoration (B) for wetlands in the mainstream nations from 2000 to 2018
Fig. 7 The percentage of scientific papers on phytoremediation (A) and engineering restoration (B) for wetlands published by the mainstream institutions of international nations (in blue) and China (in red) during 2000-2018

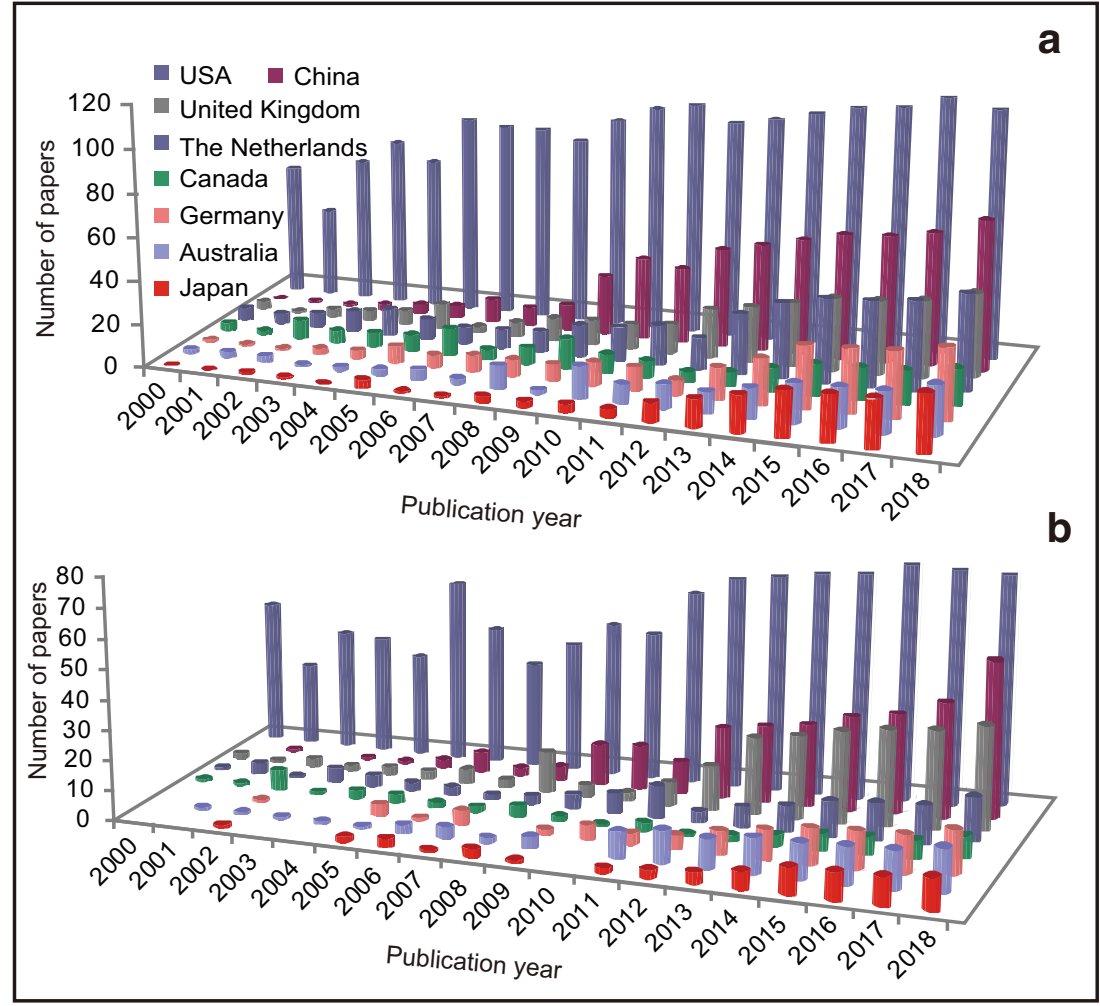

Percentage (\%)

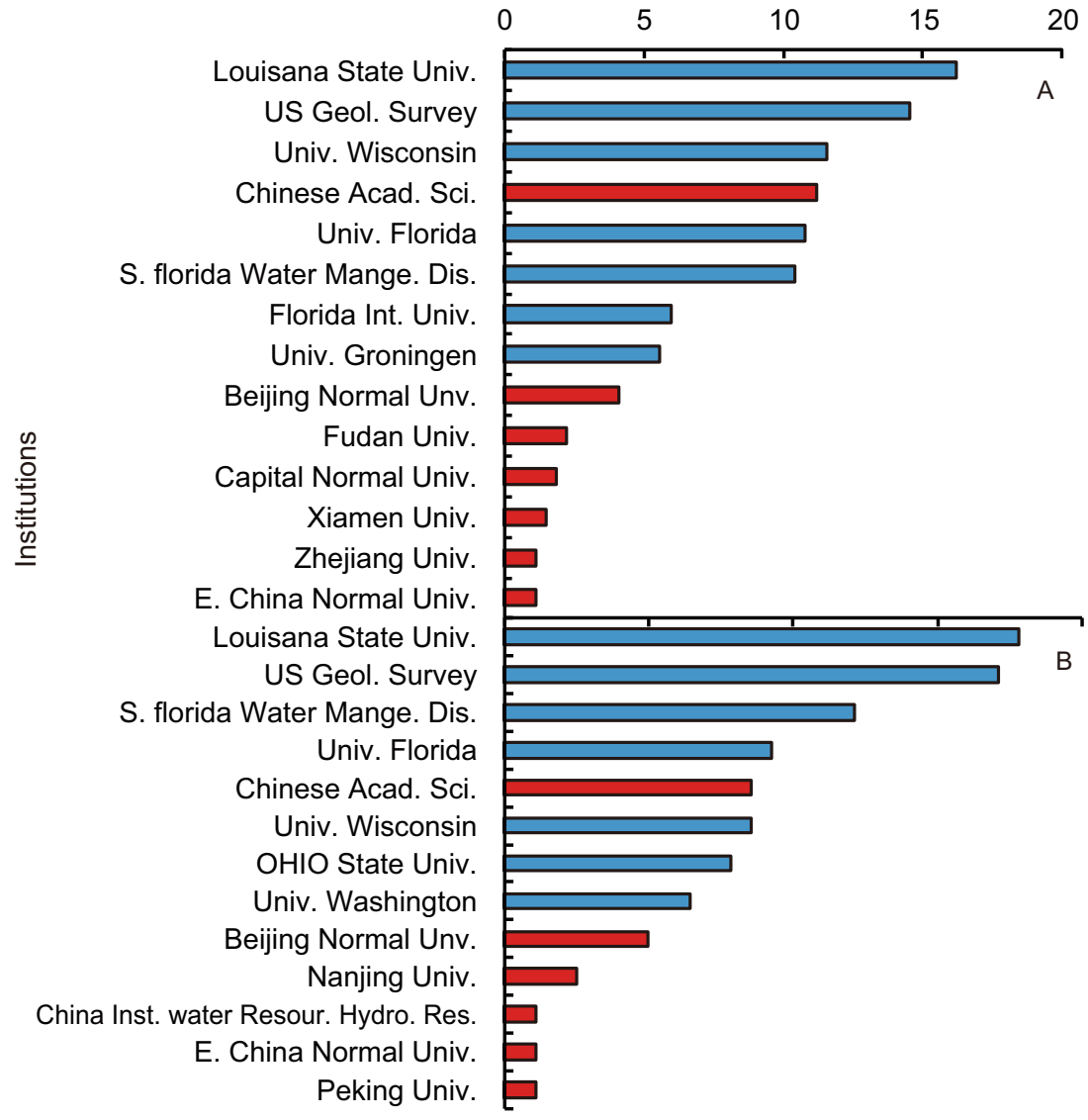


techniques which published by Chinese Academy of Sciences ranked fourth and fifth, respectively, in the world and first in China. The Beijing Normal University became a major research institution only behind of CAS in China on wetland ecological restoration (Fig. 7A, B).

\section{Trends in the Development of Degraded Wetland Restoration in China}

Based on the wetland ecological restoration practices in China and international states, the bioremediation technology received a great attention in developed countries and great deal of fund was invested on bioremediation research and practice. In accordance with principles of substrate design, biological population selection, community structure design and landscape design, the eight wetland ecological restoration techniques of lakeside wetland engineering technique, aquatic vegetation remediation technique, artificial floating island technique, natural-imitated dam engineering technique, artificial medium purification engineering technique, grass and forest combined ecosystem engineering technique, river corridor bioremediation technique and lakeside zone sewage and wastewater treatment engineering technique were summarized currently in China (Peng et al. 2003; Liao and Huang 2013; Ren et al. 2015; Liu and Mou 2016; Shang et al. 2016; Cui et al. 2018). Those techniques have greatly promoted the development of ecological restoration protection of China. Based on the international development trend of ecological restoration, the study and practice of biological combined restoration technology will get more and more attention on future wetland restoration research in China. In the process of wetland bioremediation technology research, the one hand is that the indigenous species with high purification capacity should be actively selected and used, the other hand is that the species with high capabilities of pollution-tolerance and decontamination should be introduced based on results of enough tests and risk assessments. Because of different functions and interrelation of plants and microorganisms in bioremediation, combination of phytoremediation and microbial restoration can get a preferable effect for damaged wetlands restoration. Meanwhile, the application of gene engineering technology in bioremediation field to breed wetland plants and microorganisms with high salt-tolerance, decontamination and high biomass will greatly promote the application of bioremediation technology in wetland restoration.

Acknowledgments We are grateful for support from the National Key R\&D Program of China (2017YFC0505902), the Key Program from the National Natural Science Foundation of China (U1806218, U1706220) and the Project of the Cultivation Plan of Superior Discipline Talent Teams of Universities in Shandong Province: "the Coastal Resources and Environment team for Blue-Yellow Area".

\section{Compliance with Ethical Standards}

Conflict of Interests The authors declare that there is no conflict of interests regarding the publication of this paper.

\section{References}

Acreman MC, Fisher J, Stratford CJ, Mould DJ, Mountford JO (2007) Hydrological science and wetland restoration: some case studies from Europe. Hydrology and Earth System Sciences 11(1):158-169

Ahmed F (2014) Cumulative hydrologic impact of wetland loss: numerical modeling study of the Rideau River watershed, Canada. Journal of Hydrologic Engineering 19(3):593-606

Allen AO, Feddema JJ (1996) Wetland loss and substitution by the section 404 permit program in southern California, USA. Environmental Management 20(2):263-274

Aselmann I, Crutzen PJ (1989) Global distribution of natural fresh-water wetlands and rice paddies, their net primary productivity, seasonality and possible methane emissions. Journal of Atmospheric Chemistry 8(4):307-358

Bartels RM, Anderson MW (1993) Wetland restoration considerations. Integrated Resource Management \& Landscape Modification for Environmental Protection 93(13):103-108

Beas BJ, Smith LM, Hickman KR, LaGrange TG, Stutheit R (2013) Seed bank responses to wetland restoration: do restored wetlands resemble reference conditions following sediment removal? Aquatic Botany 108:7-15

Bijlmakers LL, Deswart EOAM (1995) Large-scale wetland-restoration of the ronde-Venen, the Netherlands. Water Science and Technology 31(8):197-205

Callahan RL, Heard LP (1994) Restoration of wetlands through the wetland reserve program - a Mississippi perspective. Environmentally Sound Agriculture 94(4):447-452

Callaway JC, Sullivan G, Zedler JB (2003) Species-rich plantings increase biomass and nitrogen accumulation in a wetland restoration experiment. Ecological Applications 13(6):1626-1639

Chen Z, Yu GR, Ge JP, Sun XM, Hirano T, Saigusa N, Wang QF, Zhu XJ, Zhang YP, Zhang JH, Yan JH, Wang HM, Zhao L, Wang YF, Shi PL, Zhao FH (2013) Temperature and precipitation control of the spatial variation of terrestrial ecosystem carbon exchange in the Asian region. Agricultural and Forest Meteorology 182-183:266276

Coleman JM, Huh OK, Braud D (2008) Wetland loss in world deltas. Journal of Coastal Research 24(1A):1-14

Costanza R, dArge R, de Groot R, Farber S, Grasso M, Hannon B, Limburg K, Naeem S, RV ON, Paruelo J, Raskin RG, Sutton P, van den Belt M (1997) The value of the world's ecosystem services and natural capital. Nature 387(6630):253-260

Cui BS, Yang QC, Yang ZF, Zhang KJ (2009) Evaluating the ecological performance of wetland restoration in the Yellow River Delta, China. Ecological Engineering 35(7):1090-1103

Cui LL, Li GS, Ouyang NL, Mu FY, Yan F, Zhang YT, Huang XY (2018) Analyzing coastal wetland degradation and its key restoration technologies in the coastal area of Jiangsu, China. Wetlands 38(3):525-537

DeMeester JE, Richter DD (2010) Restoring restoration: removal of the invasive plant Microstegium vimineum from a North Carolina wetland. Biological Invasions 12(4):781-793

Elliott M, Mander L, Mazik K, Simenstad C, Valesini F, Whitfield A, Wolanski E (2016) Ecoengineering with Ecohydrology: successes and failures in estuarine restoration. Estuarine Coastal and Shelf Science 176:12-35 
Foote AL, Pandey S, Krogman NT (1996) Processes of wetland loss in India. Environmental Conservation 23(1):45-54

Foy G (1990) Oil and gas activity and Louisiana wetland loss. Journal of Environmental Management 31(3):289-297

Goodwin P (1994) Physical processes in tidal wetland restoration, In: falconer RA and Goodwin P (eds.), Wetland management. proceedings of the international conference organized by the institution of civil engineers. Thomas Telford, London, U.K.

Guan B, Yu JB, Cao D, Li YZ, Han GX, Mao PL (2013) The ecological restoration of heavily degraded saline wetland in the Yellow River Delta. Clean-Soil Air Water 41(7):690-696

Gyuracz J, Banhidi P, Csuka A (2011) Successful restoration of water level and surface area restored migrant bird populations in a Hungarian wetland. Biologia 66(6):1177-1182

Hagerthey SE, Cook MI, Mac Kobza R, Newman S, Bellinger BJ (2014) Aquatic faunal responses to an induced regime shift in the phosphorus-impacted Everglades. Freshwater Biology 59(7):13891405

Hey DL, Philippi NS (1995) Flood reduction through wetland restoration - the upper Mississippi River basin as a case-history. Restoration Ecology 3(1):4-17

Holden J, Chapman PJ, Labadz JC (2004) Artificial drainage of peatlands: hydrological and hydrochemical process and wetland restoration. Progress in Physical Geography 28(1):95-123

Holland CC, Honea JE, Gwin SE, Kentula ME (1995) Wetland degradation and loss in the rapidly urbanizing area of Portland, Oregon. Wetlands 15(4):336-345

Huang JY, Li JW, Nkrumah PN, Appiah-Sefah G (2016) Effects of recovery of wetland vegetation on active nutrients fractions in albic soils. Fresenius Environmental Bulletin 25(3):754-761

Hurry CR, James EA, Thompson RM (2013) Connectivity, genetic structure and stress response of Phragmites australis: issues for restoration in a salinising wetland system. Aquatic Botany 104:138-146

Ivajnsic D, Sajna N, Kaligaric M (2016) Primary succession on re-created coastal wetland leads to successful restoration of coastal halophyte vegetation. Landscape and Urban Planning 150:79-86

Keddy P (1999) Wetland restoration: the potential for assembly rules in the service of conservation. Wetlands 19(4):716-732

Kentula ME (2000) Perspectives on setting success criteria for wetland restoration. Ecological Engineering 15(3-4):199-209

Kesel RH (1989) The role of the Mississippi River in wetland loss in southeastern Louisiana, USA. Environmental Geology and Water Sciences 13(3):183-193

Kim KG, Lee H, Lee DH (2011) Wetland restoration to enhance biodiversity in urban areas: a comparative analysis. Landscape and Ecological Engineering 7(1):27-32

Kingsford RT, Thomas RF (2002) Use of satellite image analysis to track wetland loss on the Murrumbidgee River floodplain in arid Australia, 1975-1998. Water Science and Technology 45(11):45-53

Lamsal P, Atreya K, Ghosh MK, Pant KP (2019) Effects of population, land cover change, and climatic variability on wetland resource degradation in a Ramsar listed Ghodaghodi Lake complex, Nepal. Environmental Monitoring and Assessment 191(7). https://doi.org/ 10.1007/s10661-019-7514-0

Land L, White JR, Gambrell RP (2011) Microbial response to potential soil-stabilizing polymer amendments for coastal wetland restoration. Soil Science Society of America Journal 75(6):2398-2406

RR Lewis, JA Kusler and KL Erwin. (1994). Lessons learned from 5 decades of wetland restoration and creation in North America. Mts 94 - challenges and opportunities in the marine environment, proceedings: $233-240$

Li EH, Liu GH, Li W, Yuan LY, Li SC (2008) The seed-bank of a lakeshore wetland in Lake Honghu: implications for restoration. Plant Ecology 195(1):69-76

Li YF, Shi YL, Zhu XD, Cao HH, Yu T (2014a) Coastal wetland loss and environmental change due to rapid urban expansion in
Lianyungang, Jiangsu, China. Regional Environmental Change 14(3):1175-1188

Li YZ, Yu JB, Ning K, Du SY, Han GX, Qu FZ, Wang GM, Fu YQ, Zhan C (2014b) Ecological effects of roads on the plant diversity of coastal wetland in the Yellow River Delta. In: Ecological effects of roads on the plant diversity of coastal wetland in the Yellow River Delta. Scientific World Journal

Liao J, Huang Y (2013) The review of watershed water environment restoration technique. Environmental Science and Technology 26(1):62-65

Lin QY, Yu S (2018) Losses of natural coastal wetlands by land conversion and ecological degradation in the urbanizing Chinese coast. Scientific Reports 8

Liu Q, Mou X (2016) Interactions between surface water and groundwater: key processes in ecological restoration of degraded coastal wetlands caused by reclamation. Wetlands $36: \mathrm{S} 95-\mathrm{S} 102$

Liu XP, Kelin W, Geli Z (2004) Perspectives and policies: ecological industry substitutes in wetland restoration of the middle Yangtze. Wetlands 24(3):633-641

Ma L, He F, Sun J, Wang L, Xu D, Wu ZB (2015) Remediation effect of pond-ditch circulation on rural wastewater in southern China. Ecological Engineering 77:363-372

Ma GX, Yu F, Wang JN, Zhou X, Yuan J, Mou XH, Zhou Y, Yang WS, Peng F (2017) Measuring gross ecosystem product (GEP) of 2015 for terrestrial ecosystems in China. Environmental Science 37(4): 1474-1482

Marchetti MP, Garr M, Smith ANH (2010) Evaluating wetland restoration success using aquatic macroinvertebrate assemblages in the Sacramento Valley, California. Restoration Ecology 18(4):457-466

Martinez-Santos P, de Stefano L, Llamas MR, Martinez-Alfaro PE (2008) Wetland restoration in the Mancha occidental aquifer, Spain: a critical perspective on water, agricultural, and environmental policies. Restoration Ecology 16(3):511-521

Matthews E, Fung I (1987) Methane emission from natural wetlands: global distribution, area, and environmental characteristics of sources. Global Biogeochemical Cycles 1:61-86

McCauley LA, Jenkins DG, Quintana-Ascencio PF (2013) Isolated wetland loss and degradation over two decades in an increasingly urbanized landscape. Wetlands 33(1):117-127

Meli P, Benayas JMR, Balvanera P, Ramos MM (2014) Restoration enhances wetland biodiversity and ecosystem service supply, but results are context-dependent: a meta-analysis. PLoS One 9(4): e93507. https://doi.org/10.1371/journal.pone.0093507

Mitsch WJ (2005) Wetland creation, restoration, and conservation: a wetland invitational at the Olentangy River wetland Research Park. Ecological Engineering 24(4):243-251

WJ Mitsch, JG Gosselink (eds) (1993) In: Wet land (second edn. Van Nost rand Reinhold, New York

Mitsch WJ, Gosselink JG (2000) The value of wetlands: importance of scale and landscape setting. Ecological Economics 35(1):25-33

Moreno-Mateos D, Meli P, Vara-Rodriguez MI, Aronson J (2015) Ecosystem response to interventions: lessons from restored and created wetland ecosystems. Journal of Applied Ecology 52(6):15281537

Moss B (1983) The Norfolk Broadland - experiments in the restoration of a complex wetland. Biological Reviews of the Cambridge Philosophical Society 58(4):521-561

Nakamura K, Tockner K, Amano K (2006) River and wetland restoration: lessons from Japan. Bioscience 56(5):419-429

Paganelli D, Sconfietti R (2013) Biodiversity loss in a small riverine wetland of the Ticino river (Lombardia, northern Italy). Journal of Limnology 72(3):573-581

Parkinson RW, DeLaune RR, Hutcherson CT, Stewart J (2006) Tuning surface water management and wetland restoration programs with historic sediment accumulation rates: Merritt Island National 
Wildlife Refuge, east-Central Florida, USA. Journal of Coastal Research 22(5):1268-1277

Peng S, Ren H, Zhang Q (2003) Theories and techniques of degraded wetland ecosystem restoration. Chinese Journal of Applied Ecology 14(11):2026-2030

Peters MA, Hamilton D, Eames C (2015) Action on the ground: a review of community environmental groups' restoration objectives, activities and partnerships in New Zealand. New Zealand Journal of Ecology 39(2):179-189

Pfadenhauer J, Grootjans A (1999) Wetland restoration in Central Europe: aims and methods. Applied Vegetation Science 2(1):95106

Portnoy JW (1999) Salt marsh diking and restoration: biogeochemical implications of altered wetland hydrology. Environmental Management 24(1):111-120

Rains MC, Landry S, Rains KC, Seidel V, Crisman TL (2013) Using net wetland loss, current wetland condition, and planned future watershed condition for wetland conservation planning and prioritization, Tampa Bay watershed, Florida. Wetlands 33(5):949-963

Rebelo AJ, Emsens WJ, Meire P, Esler KJ (2018) The impact of anthropogenically induced degradation on the vegetation and biochemistry of south African palmiet wetlands. Wetlands Ecology and Management 26(6):1157-1171

Ren LJ, Wen T, Pan W, Chen YS, Xu LL, Yu LJ, Yu CY, Zhou Y, An SQ (2015) Nitrogen removal by ecological purification and restoration engineering in a polluted river. Clean-Soil Air Water 43(12):15651573

Rothe S (1995) Flood reduction through wetland restoration: the upper Mississippi River basin as a case history - commentary. Restoration Ecology 3(4):239-239

Rumm A, Foeckler F, Deichner O, Scholz M, Gerisch M (2016) Dykeslotting initiated rapid recovery of habitat specialists in floodplain mollusc assemblages of the Elbe River, Germany. Hydrobiologia 771(1):151-163

Ryan ME, Palen WJ, Adams MJ, Rochefort RM (2014) Amphibians in the climate vice: loss and restoration of resilience of montane wetland ecosystems in the western US. Frontiers in Ecology and the Environment 12(4):232-240

E. Schneider (2014). Aspects of wetland habitat restoration and monitoring in the Danube Delta: water macrophytes as quality indicators in evaluation processes. Acta Zoologica Bulgarica (Suppl. 7): 97-102

Scott DE, Metts BS (2012) Shifts in an isolated wetland salamander community over 30 yrs: has climate change altered wetland hydrology? Integrative and Comparative Biology 52:E156-E156

Shang ZH, Yang SH, Wang YL, Shi JJ, Ding LM, Long RJ (2016) Soil seed bank and its relation with above-ground vegetation along the degraded gradients of alpine meadow. Ecological Engineering 90: 268-277

Shen G, Yang XC, Jin YX, Xu B, Zhou QB (2019) Remote sensing and evaluation of the wetland ecological degradation process of the Zoige plateau wetland in China. Ecological Indicators 104:48-58

Stroh PA, Hughes FMR, Sparks TH, Mountford JO (2012) The influence of time on the soil seed bank and vegetation across a landscape-scale wetland restoration project. Restoration Ecology 20(1):103-112

Stuurman RJ, de Louw PGB (2000) The groundwater-surface water interaction in wetland restoration management in the Netherlands. Wetlands \& Remediation, An International Conference, pp 87-94

Sullivan KA, Aller RC (1996) Diagenetic cycling of arsenic in Amazon shelf sediments. Geochimica et Cosmochimica Acta 60(9):14651477

Sun TT, Lin WP, Chen GS, Guo PP, Zeng Y (2016) Wetland ecosystem health assessment through integrating remote sensing and inventory data with an assessment model for the Hangzhou Bay, China. Science of the Total Environment 566:627-640
Theiling CH, Janvrin JA, Hendrickson J (2015) Upper Mississippi River restoration: implementation, monitoring, and learning since 1986. Restoration Ecology 23(2):157-166

Tuttle RW, Gray RL (1993) Wetland restoration landscape ecology lessons learned in Germany and the Netherlands. Integrated Resource Management \& Landscape Modification for Environmental Protection 93(13):109-117

Tweel AW, Turner RE (2012) Watershed land use and river engineering drive wetland formation and loss in the Mississippi River birdfoot delta. Limnology and Oceanography 57(1):18-28

Ullah S, Faulkner SP (2006) Denitrification potential of different land-use types in an agricultural watershed, lower Mississippi valley. Ecological Engineering 28(2):131-140

Van Rees CB, Reed JM (2014) Wetland loss in Hawai'i since human settlement. Wetlands 34(2):335-350

Vellidis G, Smith MC, Leibowitz SG, Ainslie WB, Pruitt BA (2003) Prioritizing wetland restoration for sediment yield reduction: a conceptual model. Environmental Management 31(2):301-312

VivianSmith G, Handel SN (1996) Freshwater wetland restoration of an abandoned sand mine: seed bank recruitment dynamics and plant colonization. Wetlands 16(2):185-196

Wang L (2008) A review on wetland ecosystem restoration. Environmental Science and Management 33(8):152-156

Wang MJ, Qi SZ, Zhang XX (2012) Wetland loss and degradation in the Yellow River Delta, Shandong Province of China. Environmental Earth Sciences 67(1):185-188

Watts CH, Didham RK (2006) Rapid recovery of an insect-plant interaction following habitat loss and experimental wetland restoration. Oecologia 148(1):61-69

Weller JD (1995) Restoration of a South Florida forested wetland. Ecological Engineering 4(2):143-151

Wetzel PR, van der Valk AG, Toth LA (2001) Restoration of wetland vegetation on the Kissimmee River floodplain: potential role of seed banks. Wetlands 21(2):189-198

World Conservation Monitoring Centre (1990) Directory of wetlands of international importance: sites designated under the convention on wetlands of international importance. IUCN, Ramsar Convention Bureau

Yu J, Fu Y, Li Y, Han G, Wang Y, Zhou D, Sun W, Gao Y, Meixner FX (2011) Effects of water discharge and sediment load on evolution of modern Yellow River Delta, China, over the period from 1976 to 2009. Biogeosciences 8(9):2427-2435

E Zechner, P Huggenberger, R Wulser, U Geissbuhler and C Wuthrich. (2003). Effects of wetland restoration on drinking water quality: model-based evaluation with radon-222 and chloride data. Calibration and reliability in groundwater Modelling: a few steps closer to reality(277): 431-438

Zedler JB (2000) Progress in wetland restoration ecology. Trends in Ecology \& Evolution 15(10):402-407

Zentner J (1985) Wetland restoration in coastal California - a decade of management lessons. Estuaries 8(2B):A30-A30

Zhang JY, Ma KM, Fu BJ (2010) Wetland loss under the impact of agricultural development in the Sanjiang plain, NE China. Environmental Monitoring and Assessment 166(1-4):139-148

Zhao QQ, Bai JH, Huang LB, Gu BH, Lu QQ, Gao ZQ (2016) A review of methodologies and success indicators for coastal wetland restoration. Ecological Indicators 60:442-452

Zhu N, Zhao TQ, Xiao CY, Jiao LH, Zhang KF (2012) Distribution characters of soil microbial in Wuzhi part of Yellow River riparian wetland after artificial restoration. Advances in Environmental Science and Engineering 518-523:5030-5034

Publisher's Note Springer Nature remains neutral with regard to jurisdictional claims in published maps and institutional affiliations. 